\title{
Intestinal trehalase activity in a UK population: establishing a normal range and the effect of disease
}

\author{
Iain A. Murray ${ }^{1 *}$, Kathryn Coupland ${ }^{1}$, Julie A. Smith ${ }^{1}$, I. David Ansell ${ }^{2}$ and Richard G. Long ${ }^{1}$ \\ ${ }^{1}$ Departments of Gastroenterology and ${ }^{2}$ Histopathology, City Hospital, Nottingham NG5 1PB, UK
}

(Received 7 December 1998 - Revised 5 August 1999 - Accepted 14 September 1999)

\begin{abstract}
Trehalose is a disaccharide, the main dietary source being mushrooms. It has been approved as an additive in the preparation of dried food. Isolated intestinal trehalase deficiency is found in $8 \%$ of Greenlanders, but is rare elsewhere. The normal range of trehalase activity and the incidence of isolated trehalase deficiency in the UK have not been reported. Patients $(n 400)$ were investigated for suspected malabsorption. Endoscopic distal duodenal biopsies were taken for histological assessment and maltase, sucrase, lactase and trehalase estimation. Disaccharidase activities were determined by Dahlqvist's technique (Dahlqvist, 1968). Most patients ( $n$ 369) had normal duodenal histology. In these, square root transformation of trehalase activity produced a normal distribution. The normal range (mean $\pm 2 \mathrm{SD}$ ) was $4 \cdot 79-37 \cdot 12 \mathrm{U} / \mathrm{g}$ protein. One patient had an isolated borderline trehalase deficiency. The thirty-one patients with villous atrophy had significantly reduced disaccharidase activities. With ingestion of a gluten-free diet, maltase, sucrase and trehalase activities recovered to normal in most patients, whereas lactase activity did not. The normal range and very low incidence of isolated enzyme deficiency is comparable with that described in populations from the USA and mainland Europe. Activity is significantly reduced in untreated coeliac disease and recovers with treatment with a gluten-free diet. There is no place for routine determination of trehalase activity in the UK population and there should be no concern over the introduction of trehalose-containing dried foods.
\end{abstract}

\section{Disaccharidase: Coeliac disease}

Trehalose is a disaccharide found in mushrooms, algae and insect haemolymph. The high concentration of trehalose in cryptobiotic plants is responsible for their remarkable ability to go through cycles of desiccation and rehydration without injury. This has led to interest by the food industry, as the addition of trehalose to foodstuffs improves the quality of dried food (Roser, 1991 $a, b$; Roser \& Colaço, 1993).

Intestinal trehalase is a $\beta$-galactosidase which catalyses the hydrolysis of trehalose to two glucose molecules for absorption. It is present throughout the small intestine with highest levels in the proximal jejunum. Isolated trehalase deficiency occurs in at least $8 \%$ of the Greenland population (Gudmand-Høyer et al. 1988) but only three cases have been reported elsewhere (Bergoz, 1971; MadzarovováNohejlova, 1973), two of whom were first degree relatives. There are no reported studies of the incidence of intestinal trehalase deficiency in a British population.

The activities of other disaccharidases (maltase, sucrase and lactase) are low in patients with untreated coeliac disease. After treatment with a gluten-free diet, there is recovery of maltase, sucrase and sometimes lactase activities, although the latter only after several months.

The aim of this present study was to assay trehalase activity in duodenal biopsies from patients presenting with suspected malabsorption and to determine a reference range in those with normal histology. We also determined the effect of coeliac disease and its treatment on duodenal trehalase activity.

\section{Methods \\ Patients and biopsies}

Patients ( $n$ 400) with suspected malabsorption (251 women and 149 men; mean age 46.9 years, range $16-88$ years), and thirty-four patients with known coeliac disease (twentyone women and thirteen men; mean age 43.9 years, range 26-72 years), taking a gluten-free diet for at least 6 months, attended for endoscopic duodenal biopsies following overnight fast. Of the 400 patients taking a normal diet, fourteen were of South Asian origin, nine Afro-Caribbean, one Oriental, six Caucasian originally from Southern or Eastern Europe and the remainder were Caucasians of British descent. They were prepared with xylocaine throat spray and intravenous midazolam. At least three $3.7 \mathrm{~mm}$ diameter biopsies were taken from the second part of the duodenum. One was immediately flash frozen and stored in liquid

\footnotetext{
* Corresponding author: Dr Iain A. Murray, fax +44 (0) 114271 5531, email iainmurray10@hotmail.com
} 
$\mathrm{N}_{2}$ until disaccharidase estimation was performed within 2 weeks of biopsy.

\section{Disaccharidase estimation}

The specimen was placed in distilled water and homogenized (Ultra-Turrax, Ika-Kunke, Staufen, Germany; maximum speed for $15 \mathrm{~s}$ ). Disaccharidase activities (maltase, sucrase, lactase and trehalase) in the homogenate were determined by the method of Dahlqvist (1968), all assays being run in duplicate and corrected for glucose already present in the homogenate and in the substrate. Protein content was estimated by Lowry's technique (Lowry et al. 1951) using lyophilized bovine serum albumin (Sigma, Poole, Dorset, UK) as standard. Activity is expressed as U/g protein, equivalent to $\mu \mathrm{M}$ disaccharide hydrolysed/ $\mathrm{g}$ protein per min. Intra-assay variation using this method is $<6 \%$ while inter-biopsy variation in samples taken from the same level in a single patient is up to $32.4 \%$ (McIntyre et al. 1994).

\section{Statistical methods}

The frequency distributions of disaccharidase activities were examined and transformed into a normal distribution by square root transformation (McIntyre et al. 1994). Transformed values were plotted on a probit (percentage cumulative frequency) plot where the gradient of the line is a function of the variance. Values lying on the straight line were used to determine reference ranges (mean $\pm 2 \mathrm{SD}$ ) for each disaccharidase. Patients were considered to have an isolated disaccharidase deficiency if a single activity of only one enzyme lay below the normal range determined by this method. Lactase deficiency was diagnosed if the sucrase : lactase value was $>5$ (Bergoz et al. 1981; Smith et al. 1989; McIntyre et al. 1994). As lactase and trehalase values are similar in those without an isolated trehalase deficiency (Gudmand-Høyer et al. 1988), we considered that a sucrase: trehalase value $>5$ indicated an isolated trehalase deficiency.

The difference in disaccharidase activities between groups with histology was examined by ANOVA with Scheffé's F test used for post hoc comparisons. Differences in activities before and after commencing a gluten-free diet in coeliac patients were analysed by Student's paired $t$ test (two-sided). A value of $P<0.05$ was considered statistically significant.

\section{Results}

\section{Patients on normal diet}

Of the 400 patients with suspected malabsorption, 369 had normal histology of the second part of the duodenum; eighteen had partial villous atrophy and thirteen had total villous atrophy. All patients with villous atrophy had coeliac disease. No patient had giardiasis.

For the 369 patients with normal histology, maltase, sucrase, lactase and trehalase activities were positively skewed (coefficients of skewness were 3.71, 1.67, 1.49 and 1.73 respectively). Square root transformation of the disaccharidase activities gave a near normal distribution in each case (coefficients of skewness 1.26, 0.52, 0.05 and 0.33 respectively).

Maltase, sucrase and trehalase activities. When transformed values were plotted on a probit (percentage cumulative frequency) plot, values for $\sqrt{\text { maltase, }} \sqrt{ }$ sucrase and $\sqrt{ }$ trehalase were found to lie on straight lines, i.e. were from a single population with a normal distribution (Fig. 1). There was some discrepancy at the upper ranges. The reference ranges for maltase, sucrase and trehalase are $49.01-382.79,15 \cdot 12-97 \cdot 16$ and $4.79-37.12 \mathrm{U} / \mathrm{g}$ protein respectively. Two patients had trehalase activities below this normal range and sucrase: trehalase values $>5$. The first also had low lactase and maltase activities. Repeat biopsies showed completely normal disaccharidase activities. The second had a trehalase activity of $4.48 \mathrm{U} / \mathrm{g}$ protein (sucrase : trehalase value 9.0).

Disaccharidase activity in biopsies from the second part of the duodenum are $40 \%$ lower than those from biopsies at the ligament of Treitz or more distal (Bergoz et al. 1981; Smith et al. 1989). Hence it is possible to compare normal ranges with other studies where jejunal biopsies were performed (Table 1).

\section{Lactase activity}

$\checkmark$ Lactase values were from three subpopulations with different gradients seen on the probit plot (Fig. 1). The first group with $\sqrt{ }$ lactase activity $>2.7$ ( $n$ 313) gave a reference range of 5.71-54.89 U/g protein. There was a second group of patients with very low lactase activity of $<2.25 \mathrm{U} / \mathrm{g}$ protein $(n 16)$ and a third group with intermediate lactase activity $(n 40)$. Sucrase : lactase values $>5$ were seen in the entire group with low lactase activity and in twenty-six of forty patients with intermediate activities. Two of six Southern or Eastern Europeans (33\%), eleven of fourteen (78.6\%) South Asians, eight of nine Afro-Caribbeans $(88.9 \%)$, the only Oriental subject and twenty of 339 $(5.9 \%)$ British Caucasian subjects had isolated lactase deficiency.

\section{Disaccharidase activity seen in untreated coeliac disease}

All disaccharidase activities were significantly reduced in those with partial and total villous atrophy compared with patients with normal histology (Table 2). Although activities for all disaccharidases were lower in total villous atrophy than in partial villous atrophy, this did not achieve statistical significance.

\section{Patients on a gluten-free diet}

Of the thirty-four patients on a gluten-free diet, twelve had normal villous architecture of the second part of the duodenum, twenty had partial villous atrophy and two had total villous atrophy. Disaccharidase activities correlated well with histological appearance with statistically significant lower values in partial and total villous atrophy compared with those on normal diet (Table 2).

Patients (n 12) had duodenal disaccharidase estimation performed before treatment and after taking a gluten-free diet for at least 3 months. The trehalase activity increased in 


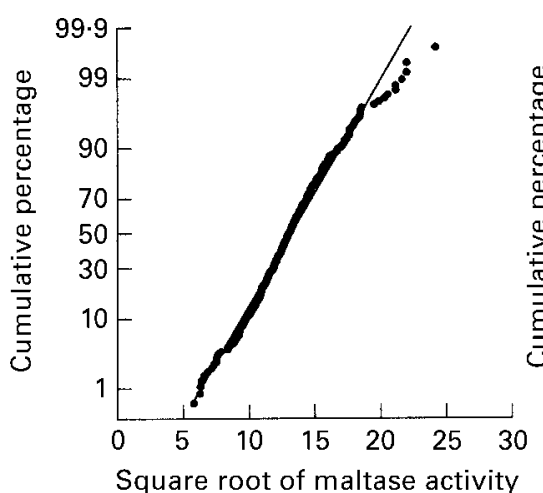

$(\sqrt{ } \mathrm{U} / \mathrm{g}$ protein)

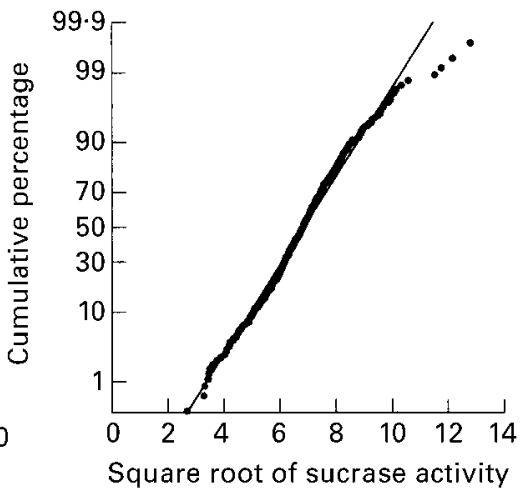

$(\sqrt{ } \mathrm{U} / \mathrm{g}$ protein)
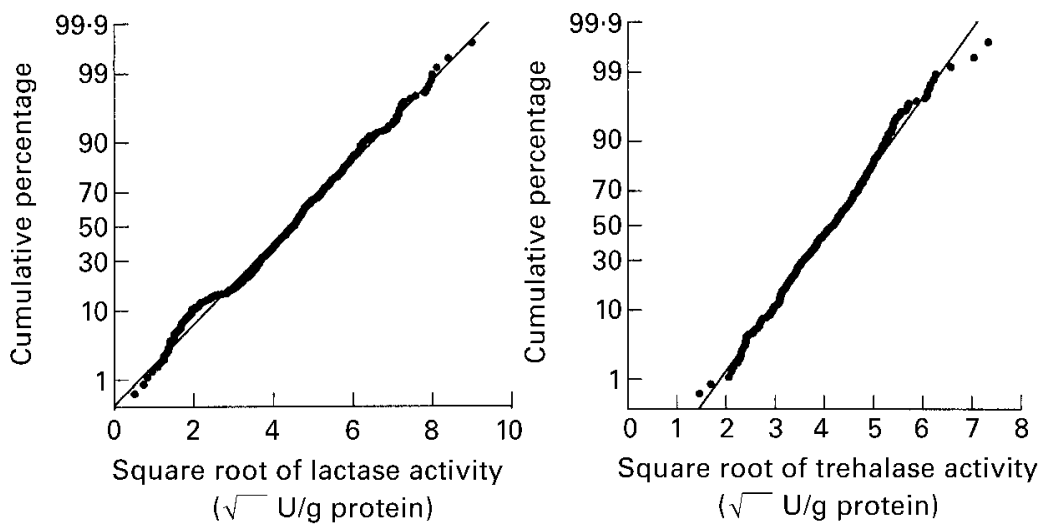

Fig. 1. Cumulative frequency plots for disaccharidase activities measured in the second part of the duodenum from 369 patients with normal histology.

Table 1. Studies of intestinal trehalase activity

\begin{tabular}{|c|c|c|c|c|c|}
\hline First author/date & Country of origin & Sample site & $\begin{array}{l}\text { Range of trehalase activity } \\
(\mathrm{U} / \mathrm{g} \text { protein })^{\star}\end{array}$ & $\begin{array}{l}\text { Patients studied } \\
(n)\end{array}$ & $\begin{array}{c}\text { Primary trehalase } \\
\text { deficient }(\%)\end{array}$ \\
\hline Asp, 1971 & Finland & Jejunal & $6 \cdot 2-27 \cdot 8$ & 35 & 0 \\
\hline Malis, $1972 \dagger$ & Czechoslovakia & Jejunal & $15 \cdot 6-24 \cdot 0$ & 15 & 0 \\
\hline Berg, 1973 & Sweden & Duodenal & 14 (median) & 178 & 0 \\
\hline Asp, 1975 & Denmark/Sweden & Jejunal & $4 \cdot 2-18$ & 19 & 0 \\
\hline Welsh, 1978 & USA & Jejunal & $8 \cdot 4-37.2$ & 187 & 0 \\
\hline Bergoz, 1981 & Switzerland & Duodenal & $6-58$ & 34 & 0 \\
\hline Jönsson, 1986 & Sweden & Duodenal & $1-21$ & 10 & 0 \\
\hline Gudmand-Høyer, 1988 & Denmark/Greenland & Jejunal & $\begin{array}{l}8-67 \\
0-67 \cdot 1\end{array}$ & 97 & $\begin{array}{l}0 \\
8\end{array}$ \\
\hline Present study & UK & Duodenal & $4 \cdot 8-37 \cdot 1$ & 369 & 0.3 \\
\hline
\end{tabular}

* If jejunal, corrected to duodenal activity by multiplying by 0.6 .

†Disaccharidase activity in supernatant fraction of homogenate measured.

Table 2. Disaccharidase activity (U/g protein) in second part of duodenum

\begin{tabular}{|c|c|c|c|c|c|c|c|c|c|c|}
\hline \multirow[b]{2}{*}{ Histology } & \multirow[b]{2}{*}{$n$} & \multirow[b]{2}{*}{ Diet } & \multicolumn{2}{|c|}{ Maltase } & \multicolumn{2}{|c|}{ Sucrase } & \multicolumn{2}{|c|}{ Lactase* } & \multicolumn{2}{|c|}{ Trehalase } \\
\hline & & & Range & Median & Range & Median & Range & Median & Range & Median \\
\hline Normal & 369 & Normal & $49 \cdot 0-382 \cdot 8$ & $170 \cdot 6$ & $15 \cdot 1-97 \cdot 2$ & $46 \cdot 7$ & $5 \cdot 7-54.9$ & 20.5 & $4 \cdot 8-37 \cdot 1$ & 17.6 \\
\hline PVA & 18 & Normal & $2.9-147.0$ & 47.5 & $0-29.5$ & $14 \cdot 1$ & $0-15.5$ & 2.9 & $0-11.3$ & 2.5 \\
\hline TVA & 13 & Normal & $1.6-111.0$ & 33.8 & $0.1-26.2$ & 8.2 & $0-7.8$ & 1.2 & $0-5 \cdot 0$ & 1.6 \\
\hline Normal & 12 & GFD & $68.2-251.5$ & $143 \cdot 6$ & $11 \cdot 7-101 \cdot 1$ & $42 \cdot 9$ & $0.4-50.6$ & $11 \cdot 6$ & $2 \cdot 5-27 \cdot 6$ & $10 \cdot 5$ \\
\hline PVA & 20 & GFD & $11 \cdot 7-191.2$ & $82 \cdot 1$ & $0.3-59.8$ & $19 \cdot 9$ & $0-12 \cdot 9$ & $3 \cdot 1$ & $0-16.5$ & 3.9 \\
\hline TVA & 2 & GFD & $19 \cdot 4-36 \cdot 5$ & $27 \cdot 3$ & $2 \cdot 2-12 \cdot 0$ & $6 \cdot 1$ & $1.0-3.8$ & $2 \cdot 2$ & $0.8-2 \cdot 11$ & 1.4 \\
\hline
\end{tabular}

PVA, partial villous atrophy; TVA, total villous atrophy; GFD, gluten-free diet.

* Lactase value for normal histology excludes lactase deficient (see p. 242). 
ten patients and recovered to normal levels in eight, compared with recovery to normal levels in nine patients for maltase and sucrase and only in four for lactase. The change in activity of every disaccharidase with a gluten-free diet was statistically significant.

\section{Discussion}

Mushrooms and products containing baker's yeast are the only sources of trehalose in the human diet. However, there is interest in the food industry in trehalose, as its addition to foodstuffs before air-drying produces dried food with a long shelf-life. Rehydration produces food with the same taste and even aroma of the fresh product.

Ingestion of a disaccharide in an individual who cannot digest it results in osmotic diarrhoea, abdominal pain and increased rectal flatulence. It is therefore important to establish the incidence of trehalase deficiency in a population before introducing trehalose-dried foods.

In the present study we have examined 400 patients with suspected malabsorption and found one with possible primary trehalase deficiency. The incidence of primary trehalase deficiency in the UK must be extremely low. In Greenland, there is an incidence of at least $8 \%$ (Gudmand-Høyer et al. 1988) but the incidence in the USA (Welsh et al. 1978), Finland (Asp et al. 1975), Czechoslovakia (Malis et al. 1972), Sweden (Berg et al. 1973; Jönsson et al. 1986), Denmark (Gudmand-Høyer \& Skovbjerg, 1996) and Switzerland (Bergoz et al. 1981) has been zero. Although these studies are not directly comparable, the normal ranges vary little throughout the USA and northern Europe (Table 1). The discrepancy from the normal range at higher disaccharidase activities has previously been noted for maltase and sucrase (McIntyre et al. 1994).

In untreated coeliac disease, the activity of all intestinal disaccharidases is greatly reduced. The median activity in untreated coeliac disease (total villous atrophy compared with those with normal histology) was reduced by $80.2 \%$, $82.5 \%, 94.0 \%$ and $91.1 \%$ for maltase, sucrase, lactase and trehalase activity respectively. This is similar to that seen in previous studies (Berg et al. 1973; Langman \& Rowland, 1990). Of our thirty-one patients with coeliac disease taking a normal diet, six patients had no detectable trehalase activity, seven no detectable lactase activity and four no detectable sucrase activity. All had generalized decreases in disaccharidase activities.

In those patients studied before and after starting a glutenfree diet, maltase, sucrase and trehalase activities recovered in almost all when measurement of activities was repeated after 3-35 months (median 7 months) on the diet. Histological improvement may be seen within 4 weeks of commencing the diet (Dissanayake et al. 1974). Delayed recovery of lactase activity measured in proximal jejunal biopsies is well recognized, but may not be clinically important. Bodé \& Gudmand-Høyer (1988) found low lactase activity in $56 \%$ of jejunal biopsies but found an abnormal lactose tolerance test in only $12 \%$ and a specific deficiency in only half of these. As the incidence of primary lactase deficiency in a Danish population is $6 \%$, it was concluded that the distal small bowel compensated for low levels proximally and that in well-treated coeliac disease, low lactase activity measured on biopsy was of no clinical relevance. Colonic bacteria in lactose intolerant subjects adapt to lactose ingestion and reduce the symptomatic response to lactose (Hertzler \& Savaiano, 1996). The incidence of primary lactase deficiency in British white subjects is 3.2-6\% (Ferguson et al. 1984; Duncan et al. 1994; Gudmand-Høyer \& Skovbjerg, 1996) so it is unlikely that $67 \%$ with low lactase activity represents primary lactase deficiency in treated coeliac disease. Using sucrase: lactase and sucrase: trehalase values in patients with coeliac disease is less reliable than in patients with normal villous architecture because of the variable effect the disease has on enzyme activity. We did not investigate the relevance of low lactase levels in our coeliac patients who were taking a gluten-free diet, but none of them suffered from diarrhoea or weight loss on the diet.

Two separate populations of lactase-deficient patients, one with 'intermediate low' levels of lactase and one with very low levels have been reported in previous studies (Asp et al. 1971; McIntyre et al. 1994). Examining the sucrase : lactase values shows that $65 \%$ of the latter group have an isolated lactase deficiency.

In conclusion, we have examined 369 UK patients with normal duodenal histology and defined a normal range for trehalase activity in biopsies from the second part of the duodenum of $4 \cdot 79-37 \cdot 12 \mathrm{U} / \mathrm{g}$ protein. One patient may have a primary intestinal trehalase deficiency, although activity was only just below the normal range. Trehalase activity is decreased in untreated coeliac disease and recovers to normal in most patients within 6 months of starting a gluten-free diet. We cannot recommend routine intestinal trehalase estimation in the UK for the investigation of unexplained diarrhoea.

\section{References}

Asp N-G, Berg NO, Dahlqvist A, Jussilla J \& Salmi H (1971) The activity of three different small-intestinal $\beta$-galactosidases in adults with and without lactase deficiency. Scandinavian Journal of Gastroenterology 6, 755-762.

Asp N-G, Gudmand-Høyer E, Anderson B, Berg NO \& Dahlqvist A (1975) Distribution of disaccharidases, alkaline phosphatase, and some intracellular enzymes along the human small intestine. Scandinavian Journal of Gastroenterology 10, 647-651.

Berg NO, Dahlqvist A, Lindberg T \& Nordén A (1973) Correlation between morphological alterations and enzyme activities in the mucosa of the small intestine. Scandinavian Journal of Gastroenterology 8, 703-712.

Bergoz R (1971) Trehalose malabsorption causing intolerance to mushrooms. Gastroenterology 60, 909-912.

Bergoz R, Griessen M, Infante F, de Peyer R \& Vallotton M-C (1981) Significance of duodenal disaccharidases. Digestion 22, $108-112$.

Bodé S \& Gudmand-Høyer E (1988) Incidence and clinical significance of lactose malabsorption in adult coeliac disease. Scandinavian Journal of Gastroenterology 23, 484-488.

Dahlqvist A (1968) Assay of intestinal disaccharidases. Analytical Biochemistry 22, 99-107.

Dissanayake AS, Jerrome DW, Offord RE, Truelove SC \& Whitehead R (1974) Identifying toxic fractions of wheat gluten and their effect on the jejunal mucosa in coeliac disease. Gut 15, 931-946.

Duncan A, Park RPR, Lee FD \& Russell RI (1994) A retrospective analysis of the clinical value of jejunal disaccharidase analysis. Scandinavian Journal of Gastroenterology 29, 1111-1116. 
Ferguson A, MacDonald DM \& Brydon WG (1984) Prevalence of lactase deficiency in British adults. Gut 25, 163-167.

Gudmand-Høyer E, Fenger HJ, Skovbjerg H, Kern-Hasen P \& Rørbæk Madsen P (1988) Trehalase deficiency in Greenland. Scandinavian Journal of Gastroenterology 23, 775-778.

Gudmand-Høyer E \& Skovbjerg H (1996) Disaccharidase digestion and maldigestion. Scandinavian Journal of Gastroenterology 31, Suppl. 216, 111-121.

Hertzler SR \& Savaiano DA (1996) Colonic adaptation to daily lactose feeding in lactose maldigestors reduces lactose intolerance. American Journal of Clinical Nutrition 64, 232-236.

Jönsson K-A, Bodemar G, Tagesson C \& Walan A (1986) Variation of disaccharidase activities in duodenal biopsy specimens. Scandinavian Journal of Gastroenterology 21, 51-54.

Langman JM \& Rowland R (1990) Activity of duodenal disaccharidases in relation to normal and abnormal mucosal morphology. Journal of Clinical Pathology 43, 537-540.

Lowry OH, Rosebrough NJ, Farr AL \& Randall RJ (1951) Protein estimation with the folin-phenol reagent. Journal of Biological Chemistry 193, 262-275.

McIntyre AS, Smith JA, Amoah J, Ng D \& Long RG (1994) The use of small endoscopic biopsies in the measurement of disaccharidase activities and the effect of duodenal ulceration. European Journal of Gastroenterology and Hepatology 6, 229234.

Madzarovová-Nohejlova J (1973) Trehalase deficiency in a family. Gastroenterology 65, 130-133.

Malis F, Lojda Z, Fric P \& Jodl J (1972) Disaccharidases in celiac disease and mucoviscidosis. Digestion 5, 40-48.

Roser B (1991a) Trehalose, a new approach to premium dried foods. Trends in Food Science Technology 2, 166-169.

Roser B (1991b) Trehalose drying, a novel replacement for freezedrying. BioPharm 4, 47-52.

Roser B \& Colaço C (1993) A sweeter way to fresher food. New Scientist 138, 24-28.

Smith JA, Mayberry JF, Ansell ID \& Long RG (1989) Small bowel biopsy for disaccharidase levels: evidence that endoscopic forceps biopsy can replace the Crosby capsule. Clinica Chimica Acta 183, 317-322.

Welsh JD, Poley JR, Bhatia M \& Stevenson DE (1978) Intestinal disaccharidase activities in relation to age, race and mucosal damage. Gastroenterology 75, 847-855. 